\title{
An Overview of Natural Polysaccharides as Biological Macromolecules: Their Chemical Modifications and Pharmaceutical Applications
}

Harshal Ashok Pawar*, Swati Ramesh Kamat and Pritam Dinesh Choudhary

Dr. L. H. Hiranandani College of Pharmacy, Ulhasnagar-421003, Maharashtra, India

\begin{abstract}
Any pharmaceutical formulation contains two ingredients one is the active ingredient and other is an excipients. An excipient helps in the manufacturing of dosage form and it also improves physicochemical parameters of the dosage form. Polymers play an important role as excipients in pharmaceutical dosage form. They influence drug release and should be compatible, non-toxic, stable, economic etc. Biopolymers, synthetic polymers and their derivatives are commonly used in medicine and pharmacy. They are broadly classified as natural polymers and synthetic polymers. Nowadays, due to many problems associated with drug release and side effects manufacturers are inclined towards using natural polymers and their derivatives. Natural polymers are basically polysaccharides so they are biocompatible and without any side effects. This review article aims at discussing various sources, pharmaceutical applications and the different techniques used for modification of natural polymers.
\end{abstract}

Keywords: Natural polymer; Polysaccharides; Grafting

\section{Introduction}

A polymer is macromolecules composed of repeating structural units which are connected by covalent chemical bonds (Figure 1). The term "polymer" is derived from the ancient Greek word polus which means "many or much" and meros, meaning "parts". It refers to a molecule whose structure is composed of multiple repeating units, having a characteristic of high relative molecular mass and attendant properties. The units composing polymers derive from low relative molecular mass molecule. The term was coined in 1833 by Jöns Jacob Berzelius, though with a definition distinct from the modern IUPAC definition [1]

Polysaccharides are a diverse class of polymeric materials of natural (animal, plant, algal) origin formed via glycosidic linkages of monosaccharides [2]. Depending upon the nature of the monosaccharide unit, polysaccharides are classified as linear or branched chain polysaccharides. Polysaccharides possess a number of reactive functional groups in their chemical structure, including hydroxyl, amino, and carboxylic acid groups, indicating the possibility for chemical modification [3]. Molecular weight of naturally occurring polysaccharide varies between hundreds to thousands of Daltons, further increasing diversity [4].

Although synthetic and natural polymers are available, the use of

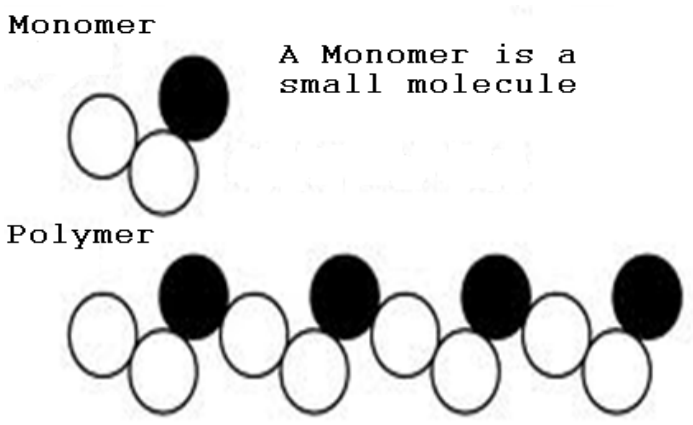

A polymer is a long chain molecule

Figure 1: Structure of monomers and polymers. natural polymers for pharmaceutical applications is attractive because they are economical, readily available and non-toxic. They are capable of chemical modifications, potentially biodegradable and with few exceptions, also biocompatible [5]. Substances of plant origin pose several disadvantages like being synthesized in small quantities and in mixtures that are structurally complex, which may differ according to the location of the plants as well as other variables such as the season. This may result in a slow and expensive isolation and purification process. Also there is another issue which is become increasingly important is that of intellectual property rights [6,7]. The plant-derived polymers not only have applications in pharmaceutical formulations like their use in the manufacture of solid monolithic matrix systems, implants, films, beads, microparticles, nanoparticles, inhalable and injectable systems but also in viscous liquid formulations [8-10]. In these dosage forms, polymeric materials play different roles such as binders, matrix formers or drug release modifiers, film coating formers, thickeners or viscosity enhancers, stabilizers, disintegrants, solubilisers, emulsifiers, suspending agents, gelling agents and bioadhesives [11].

\section{Different Sources, Chemical Composition and Applica- tions of Natural Polysaccharides}

Table 1-6 provides the information regarding source, chemical constituents and application of different natural polysaccharides.

\section{Modification of Natural Polymers}

The intrinsic structure and properties of nonionic, anionic, and cationic gums make them found extensive application in various

${ }^{*}$ Corresponding author: Harshal Ashok Pawar, Assistant Professor and Head of Department (Quality Assurance), Dr. L. H. Hiranandani College of Pharmacy, Smt. CHM Campus, Opp. Ulhasnagar Railway Station, Ulhasnagar-421003, Maharashtra, India; Tel: +91-8097148638; E-mail: harshal.dlhhcop@gmail.com

08, 2015

Citation: Pawar HA, Kamat SR, Choudhary PD (2015) An Overview of Natural Polysaccharides as Biological Macromolecules: Their Chemical Modifications and Pharmaceutical Applications. Biol Med (Aligarh) 6: 224. doi: 10.4172/09748369.1000224

Copyright: $\odot 2015$ Pawar HA, et al. This is an open-access article distributed under the terms of the Creative Commons Attribution License, which permits unrestricted use, distribution, and reproduction in any medium, provided the original author and source are credited. 
Citation: Pawar HA, Kamat SR, Choudhary PD (2015) An Overview of Natural Polysaccharides as Biological Macromolecules: Their Chemical Modifications and Pharmaceutical Applications. Biol Med (Aligarh) 6: 224. doi: 10.4172/0974-8369.1000224

Page 2 of 9

\begin{tabular}{|c|c|c|c|c|}
\hline Common name & Botanical name & Chemical constituents & Application & References \\
\hline $\begin{array}{c}\text { Okra (Lady's finger, Gumbo, } \\
\text { Bhindi) }\end{array}$ & $\begin{array}{c}\text { Abelmoschus esculentus } \\
\text { (Malvaceae) }\end{array}$ & $\begin{array}{l}\text { Galactose, galacturonic acid, and rhamnose and with } \\
\text { some fractions of glucose, mannose, arabinose and } \\
\text { xylose }\end{array}$ & Suspending agent, disintegrating agent & {$[12-14]$} \\
\hline $\begin{array}{l}\text { Phoenix mucilage (Date palm, } \\
\text { Pindakharjura, Khajur) }\end{array}$ & $\begin{array}{l}\text { Phoenix dactylifera } \\
\text { (Palmaceae) }\end{array}$ & $\begin{array}{l}\text { Fructose, sucrose, mannose, glucose and maltose in } \\
\text { addition to small amounts of polysaccharides such as } \\
\text { pectin }(0.5-3.9 \%) \text {, starch and cellulose }\end{array}$ & Binder & [15] \\
\hline $\begin{array}{l}\text { Cordia Mucilage (Bhokar, } \\
\text { Semar, Vidi) }\end{array}$ & $\begin{array}{l}\text { Cordia Obliqua } \\
\text { (Boraginaceae) }\end{array}$ & Arabinose, galactose, pyrralinose & $\begin{array}{l}\text { Expectorant, gonorrhoea treatment, } \\
\text { tablet binder, emulsifier }\end{array}$ & [16] \\
\hline Jackfruit (Ceylon jack) & $\begin{array}{c}\text { Artocarpus heterophyllus } \\
\text { (Moraceae) }\end{array}$ & Galactomannans, starch & $\begin{array}{l}\text { Suspending agent, emulsifying agent, } \\
\text { Binder, mucoadhesive, release retardant }\end{array}$ & {$[17,18]$} \\
\hline
\end{tabular}

Table 1: Source, chemical constituents and application of polysaccharides obtained from fruits.

\begin{tabular}{|c|c|c|c|c|}
\hline Common name & Botanical name & Chemical constituents & Applications & References \\
\hline $\begin{array}{l}\text { Tamarind seed polysaccharide } \\
\text { (Imli, Chinch) }\end{array}$ & Tamarindus indica (Fabaceae) & $\begin{array}{c}\text { Glucosyl : xylosyl : galactosyl in the } \\
\text { ratio of } 3: 2: 1\end{array}$ & $\begin{array}{l}\text { Formulation of matrix tablets, } \\
\text { biodegradable carrier for colon specific } \\
\text { drug delivery, novel bioadhesive }\end{array}$ & {$[19,20]$} \\
\hline Fenugreek mucilage (Methi) & $\begin{array}{l}\text { Trigonella foenum-graceum } \\
\text { (Leguminosae) }\end{array}$ & Galactomannans & Matrix formulation, release retardant. & [21] \\
\hline Locust Bean Gum (carob gum) & Ceretonia Siliqua (Leguminosae) & $\begin{array}{l}\text { D-galacto-D-mannoglycan, } \\
\text { cellulose, pentan, galactomannan. }\end{array}$ & $\begin{array}{l}\text { Superdisintegrant, in controlled delivery } \\
\text { system, in colonic drug delivery. }\end{array}$ & [22-24] \\
\hline $\begin{array}{l}\text { Tara gum (Taya, } \\
\text { Spiny hold back) }\end{array}$ & $\begin{array}{c}\text { Caesalpinia spinosa (Leguminosae or } \\
\text { Fabaceae) }\end{array}$ & Mannose : galactose in ratio $3: 1$ & $\begin{array}{l}\text { Thickening agent, stabilizer, in formulation } \\
\text { of gastroretentive controlled release tablets }\end{array}$ & [25] \\
\hline $\begin{array}{l}\text { Honey locust gum (Thorny } \\
\text { Locust) }\end{array}$ & Gleditsia triacanthos (Leguminosea) & galactomannan & In formulation of matrix tablets. & {$[26]$} \\
\hline $\begin{array}{l}\text { Cassia Tora mucilage (Tarota, } \\
\text { Takla, Cassia semen) }\end{array}$ & Cassia tora (Caesalpiniaceae) & Arabinose and glucose & Binding, suspending agent. & {$[27,28]$} \\
\hline Mimosa scrabella & Mimosa scabrella (Mimosaceae) & $\begin{array}{l}\text { Galctomannan -mannose: } \\
\text { galactose ratio of 1.1:1. }\end{array}$ & Release-controlling agent & [29] \\
\hline $\begin{array}{l}\text { Mimosa pudica (Touch-me-not, } \\
\text { Chui-mui, Lajalu) }\end{array}$ & Mimosa pudica (Mimosaceae) & d-Xylose and d-glucuronic acid. & $\begin{array}{c}\text { Swelling agent, in formulation of controlled } \\
\text { delivery system }\end{array}$ & {$[30]$} \\
\hline $\begin{array}{l}\text { Ocimum mucilage (Sweet basil, } \\
\text { Ram Tulsi, Sabje, Sabza) }\end{array}$ & Ocimum americanum (Lamiaceae) & $\begin{array}{l}\text { Xylose, arabinose, rhamnose and } \\
\text { galacturonic acids }\end{array}$ & Tablet disintegrant & {$[31,32]$} \\
\hline Black gram (urad dal) & Vigna mungo (Fabaceae) & $\begin{array}{c}\text { Protein, fat, } \\
\text { fibre, minerals, carbohydrates }\end{array}$ & $\begin{array}{l}\text { Suspending agent, matrix forming agent } \\
\text { for sustained release tablet. }\end{array}$ & {$[33,34]$} \\
\hline Gulmohar mucilage (goldmohar) & Delonix regia (Fabaceae) & Glucomannose & Tablet binder & [35] \\
\hline
\end{tabular}

Table 2: Source, chemical constituents and application of polysaccharides obtained from seeds.

\begin{tabular}{|c|c|c|c|c|}
\hline Common name & Botanical name & Chemical constituents & Applications & References \\
\hline $\begin{array}{l}\text { Albizia gum (Albizia Brownie, } \\
\text { Inga zygia) }\end{array}$ & $\begin{array}{l}\text { Albizia zygia } \\
\text { (Leguminosae) }\end{array}$ & Galactose & Emulsifier, tablet coating. & {$[36,37]$} \\
\hline Almond gum (Almond, badam) & $\begin{array}{l}\text { Prunus amygdalus } \\
\text { (Rosaceae) }\end{array}$ & $\begin{array}{l}\text { Aldobionic acid, L-arabinose, L-galactose, } \\
\text { D-mannose }\end{array}$ & $\begin{array}{l}\text { Emulsifier, suspending agent, glazing } \\
\text { agent, stabilizer, thickner, binder }\end{array}$ & {$[38]$} \\
\hline Cashew gum (cashew, kaju) & $\begin{array}{l}\text { Anacardium occidentale } \\
\text { (Anarcardiaceae) }\end{array}$ & $\begin{array}{c}\text { Galctose, arabinose, rhamnose, glucose, } \\
\text { glucuronic acid }\end{array}$ & $\begin{array}{l}\text { Gelling agent, binder, used in formulation } \\
\text { of controlled delivery system }\end{array}$ & [39-41] \\
\hline $\begin{array}{l}\text { Moringa oleifera gum (Moringa, } \\
\text { drumstick tree, benzoil tree) }\end{array}$ & $\begin{array}{l}\text { Moringa oleifera } \\
\text { (Moringaceae) }\end{array}$ & arabinose, galactose and glucoronic acid & $\begin{array}{c}\text { Gelling agent, binder, release retardant, } \\
\text { disintegrant }\end{array}$ & [42-44] \\
\hline $\begin{array}{c}\text { Gum damar (Black Dammar, } \\
\text { Indian white mahogany, Daamar) }\end{array}$ & $\begin{array}{l}\text { Shorea wiesneri } \\
\text { (Dipterocarpaceae) }\end{array}$ & Beta and alpha resins, dammarol acid & $\begin{array}{l}\text { Binder, sustained release matrix, } \\
\text { microencapsulating agent }\end{array}$ & {$[45,46]$} \\
\hline $\begin{array}{l}\text { Gum Copal (Indian copal tree, } \\
\text { Malabar tallow tree, Chandrusa) }\end{array}$ & $\begin{array}{l}\text { Bursera bipinnata } \\
\text { (Burseraceae) }\end{array}$ & $\begin{array}{l}\text { Agathic acid, cis-communic acid, trans-communic } \\
\text { acid, polycommunic acid, sandaracopimaric acid, } \\
\text { agathalic acid, monomethyl ester of agathalic } \\
\text { acid, agatholic acid and acetoxy agatholic acid }\end{array}$ & $\begin{array}{c}\text { Swelling agent, release retardant, film } \\
\text { forming agent, carrier for colon specific } \\
\text { drug delivery }\end{array}$ & {$[45,47,48]$} \\
\hline $\begin{array}{c}\text { Kondagogu Gum (Bombax } \\
\text { gossypium, Maximilianea } \\
\text { gossypium, Galgal, Ganeri, } \\
\text { Kondagogu) }\end{array}$ & $\begin{array}{l}\text { Cochlospermum } \\
\text { religiosum (Bixaceae) }\end{array}$ & $\begin{array}{l}\text { Rhamnose, galacturonic acid, glucuronic acid, } \\
\text { D-glucose, galactose, arabinose, mannose and } \\
\text { fructose }\end{array}$ & $\begin{array}{l}\text { In formulation of Gastric floating drug } \\
\text { delivery system, emulsifier }\end{array}$ & [49-51] \\
\hline $\begin{array}{l}\text { Bhara gum (Vibhitaka, Aksha, } \\
\text { Belleric myrobalan) }\end{array}$ & $\begin{array}{l}\text { Terminalia bellerica } \\
\text { (Combretaceae) }\end{array}$ & $\begin{array}{l}\text { ß- sitosterol, gallic acid, ellagic acid, ethyl gallate, } \\
\text { galloyl glucose and chebulaginic acid }\end{array}$ & Release retardant & [52] \\
\hline Hakea gum & $\begin{array}{l}\text { Hakea gibbosa } \\
\text { (Proteaceae) }\end{array}$ & $\begin{array}{l}\text { L-arabinose and D-galactose, glucuronic acid, } \\
\text { mannose, xylose }\end{array}$ & $\begin{array}{l}\text { Mucoadhesive, release retardant, } \\
\text { bioadhesive polymer }\end{array}$ & {$[53,54]$} \\
\hline Grewia gum & Grewia mollis (Tiliaceae) & Glucose, rhamnose & $\begin{array}{l}\text { Binder, film forming agent, release } \\
\text { retardant }\end{array}$ & [55-58] \\
\hline $\begin{array}{c}\text { Olibanum gum (Indian } \\
\text { frankincense, Shallaki, Dhupali) }\end{array}$ & $\begin{array}{l}\text { Boswellia serrate } \\
\text { (Burseraceae) }\end{array}$ & Resin acids, polysaccharides, boswellic acid & $\begin{array}{l}\text { Matrix forming agent, binder, } \\
\text { microencapsulating agent }\end{array}$ & {$[59-61]$} \\
\hline Terminalia gum & $\begin{array}{l}\text { Terminalia randii } \\
\text { (Combretaceae) }\end{array}$ & $\begin{array}{l}\text { B- sitosterol, gallic acid, ellagic acid, ethyl gallate, } \\
\text { galloyl glucose and chebulaginic acid }\end{array}$ & Binder & [62] \\
\hline
\end{tabular}

Table 3: Source, chemical constituents and application of polysaccharides obtained from Exudates. 
Citation: Pawar HA, Kamat SR, Choudhary PD (2015) An Overview of Natural Polysaccharides as Biological Macromolecules: Their Chemical Modifications and Pharmaceutical Applications. Biol Med (Aligarh) 6: 224. doi: 10.4172/0974-8369.1000224

Page 3 of 9

\begin{tabular}{|c|c|c|c|c|}
\hline Common name & Botanical name & Chemical constituents & References \\
\hline Cocculus mucilage (moonseed) & $\begin{array}{c}\text { Cocculus hirsutus } \\
\text { (Menispermaceae) }\end{array}$ & Polysaccharides and a gelatinous material & $\begin{array}{c}\text { Pharmaceutically used as } \\
\text { binding agent, gelling agent }\end{array}$ & [63] \\
\hline $\begin{array}{c}\text { Aloe mucilage (Aloe, } \\
\text { Gheekumari, Korpad) }\end{array}$ & $\begin{array}{c}\text { Aloe barbadensis } \\
\text { (Liliaceae) }\end{array}$ & $\begin{array}{c}\text { Contains 1, 8 dihydroxy anthraquinone derivatives and their } \\
\text { glycosides, Acemannan, arabinan, arabinorhamnogalactan, } \\
\text { galactan, galactogalacturan, glucogalactomannan, } \\
\text { galactoglucoarabinomannan and glucuronic acid. }\end{array}$ & $\begin{array}{c}\text { Formulation of controlled } \\
\text { delivery system. }\end{array}$ \\
\hline $\begin{array}{c}\text { Hibiscus mucilage (shoe-flower } \\
\text { plant, China rose, and Chinese } \\
\text { hibiscus) }\end{array}$ & $\begin{array}{c}\text { Hibiscus } \\
\text { rosa-sinensis } \\
\text { (Malvaceae) }\end{array}$ & $\begin{array}{c}\text { L-rhamnose, D-galactose, Dgalactouronic } \\
\text { acid, and D- glucuronic acid }\end{array}$ & Sustained release matrix \\
\hline
\end{tabular}

Table 4: Source, chemical constituents and application of polysaccharides obtained from Leaves.

\begin{tabular}{|c|c|c|c|c|}
\hline Common name & Botanical name & Chemical constituents & Applications & References \\
\hline \multicolumn{5}{|c|}{ Polysaccharides obtained from whole plants } \\
\hline $\begin{array}{l}\text { Neem gum (Neem, } \\
\text { Cherish) }\end{array}$ & $\begin{array}{l}\text { Azadirachta indica } \\
\quad(\text { Meliaceae) }\end{array}$ & $\begin{array}{l}\text { Mannose, glucosamine, arabinose, galactose, fucose, xylose and } \\
\text { glucose }\end{array}$ & Binder, release retardant & {$[68,69]$} \\
\hline $\begin{array}{l}\text { Moi gum (Wodier, } \\
\text { Jingini, Jhingan) }\end{array}$ & $\begin{array}{l}\text { Lannea coromandelica } \\
\text { (Anacardiaceae) }\end{array}$ & $\begin{array}{c}\text { Roots contain cluytyl ferulate; heartwood gives lanosterol; } \\
\text { bark, dlepicatechin and (+) leucocyanidin; flowers and leaves, } \\
\text { ellagic acid, quercetin and quercetin-3 arabinoside. Flowers also } \\
\text { contain iso-quercetin and morin. Leaves in addition contain beta } \\
\text { sitosterol, leucocyanidin and leucodelphinidin }\end{array}$ & $\begin{array}{c}\text { Microencapsulating agent, release } \\
\text { retardant }\end{array}$ & [70] \\
\hline \multicolumn{5}{|c|}{ Polysaccharides obtained from microbial source. } \\
\hline Curdlan & $\begin{array}{c}\text { Agrobacterium } \\
\text { spp. (Rhizobiaceae) }\end{array}$ & Glucose & $\begin{array}{l}\text { Food additive (for example, as a } \\
\text { thickener or a gelling agent), as } \\
\text { controlled delivery system. }\end{array}$ & [71] \\
\hline Gellan & $\begin{array}{c}\text { Sphingomonas } \\
\text { spp. } \\
\text { (Sphingomonadaceae) }\end{array}$ & $\begin{array}{l}\text { Glucose, } \\
\text { rhamnose } \\
\text { and glucuronate }\end{array}$ & $\begin{array}{c}\text { Culture media additive, food } \\
\text { additive (for example, as a gelling agent) } \\
\text { or for encapsulation }\end{array}$ & [71] \\
\hline Colanic acid & $\begin{array}{c}\text { Escherichia coli } \\
\text { (Enterobacteriaceae) }\end{array}$ & $\begin{array}{c}\text { Fucose, } \\
\text { glucose, } \\
\text { glucuronate and galactose }\end{array}$ & Viscosity enhancer & [71] \\
\hline K30 antigen & $\begin{array}{c}\text { Escherichia coli } \\
\text { (Enterobacteriaceae) }\end{array}$ & $\begin{array}{c}\text { Mannose } \\
\text { galactose and glucuronate }\end{array}$ & $\begin{array}{l}\text { Viscosity enhancer, controlled drug } \\
\text { releasing agent. }\end{array}$ & [71] \\
\hline
\end{tabular}

Table 5: Source, chemical constituents and application of polysaccharides obtained from Whole plant and microbial source.

\begin{tabular}{|c|c|c|c|}
\hline Common name & Botanical name & Chemical constituents & Applications \\
\hline $\begin{array}{c}\text { Konjac glucomannan (Devil's tongue, } \\
\text { voodoo lily, snake palm, or elephant yam) }\end{array}$ & $\begin{array}{c}\text { Amorphophallus konjac } \\
\text { (Araceae) }\end{array}$ & $\begin{array}{c}\text { D-Glucose and } \\
\text { D-mannose }\end{array}$ & Controlled release matrix, gelling agent, \\
\hline Taro (arvi) & $\begin{array}{c}\text { Colocasia } \\
\text { Esculenta (Araceae) }\end{array}$ & $\begin{array}{c}\text { Galactose and } \\
\text { arabinose }\end{array}$ & $\begin{array}{c}\text { Binder, mucoadhesive polymer, matrix } \\
\text { forming agent. }\end{array}$ \\
\hline
\end{tabular}

Table 6: Source, chemical constituents and application of polysaccharides obtained from Tubers.

areas, but the raw gum also emerges some drawbacks and cannot meet all application requirements for some special purpose. Thus, the modification of gums with acrive small molecules was conducted because the derivatives can not only bring the favorable properties due to the introduction of functional groups, but also keep the intrinsic advantages of gums to the greatest degree [75] and so the chemical modification always plays a dominant role to improve gums and open prospects for extending the application of raw gums. Generally, the chemical functionalization of gums mainly includes the esterification, etherification, and cross-linking reactions of hydroxyl groups.

\section{Purpose of modification}

To target at a particular site: 5 -amino salicylic acid drug used for ulcerative colitis was formulated using cross linked chitosan. It showed disintegration in intestine and absorption occurred in small intestine which wasn't seen in the formulation with chitosan [76].

To make the polymers more heat or moisture resistant: Cellulose acetate is more heat resistant than cellulose. Studies have been performed on modifications of polymers and it was found to decrease degradation rate of the polymer thus making it heat and moisture resistant [77]

To alter its solubility, more sustainable: Derivatisation of chitosan showed increased solubility in water as well as other organic solvents. Enzymatic method using hemicellulose enzyme was used to hydrolyse chitosan and reduce its molecular weight thus increasing its solubility [78]

To make it more flexible, more transparent, and more compatible and/or biodegradable: Kappa carrageenan has been subjected to play an important role as free radical scavengers in vitro and antioxidants for prevention of oxidative damage in living organisms. Although $\mathrm{k}$-carrageenan has wide application range, it suffers from certain drawback like biodegradability, which limits its use considerably [79].

Biopolymers may also have unique characteristics such as antimicrobial effects, which can be used to add value to end products: Chitosan has antimicrobial activity and it has been tried to develop by derivatisation [80].

To reduce the toxicity: Guar gum blocks your gastrointestinal track contributing to blockage of absorption of other critical substances. For example, large amounts of guar gum may prevent metformin, an antidiabetic drug, from being absorbed in the intestines. In diabetic patient where it is necessary to have stable concentration of metformin, severe fluctuation can be seen because of guar gum. This can be reduced by use of its derivative [81]. 
Structural elucidation: The degree of substitution of cellulose and its derivative can be recognized by use of NMR technique $[82,83]$.

\section{Derivatives of Natural Gums}

\section{Carboxyl derivatives}

It includes the addition of carboxyl or -COONa group on the substrate. It uses different reagent to increase the hydratability and solubility of gum. The carboxymethyl derivative of cashew gum has negative charges, and can form physical complex with the cationic polymer such as chitosan.

\section{Hydroxyethyl derivatives}

The hydroxyethyl derivatives of gum can be prepared from natural gum via an irreversible nucleophilic substitution. The derivatives show better colloid properties than the raw gums, better solubility and thermal stability in solution, good dispersibility in water, and high compatibility with anionic, cationic, and nonionic surfactants.

\section{Vinyl-functioned derivatives}

Many gums show poor reactivity and hence require addition of vinyl group so as to increase the reactivity for grafting purpose. Glycidyl methacrylate (GMA), acrylic acid, acryloyl chloride, and maleic anhydride are most commonly used modifying agents. Thus far, the vinyl-functionalized Arabic gum, guar gum, cashew gum [75], xanthan gum [76], and pectin [77] were prepared under basic condition.

\section{Cationic derivatives}

The cationic derivatives of gum have positive charges due to the introduction of cationic functional groups such as amino, ammonium, imino, sulfonium, or quaternary phosphonium groups [78,79].

\section{Amphoteric derivatives}

Amphoteric natural polymer contains both anionic and cationic substituents on its structure, which exhibits distinct properties in contrast to the individual anionic or cationic polymer and receives extensive applications in fine chemicals, papermaking, dyeing, and package materials [80-82]. The common methods to prepare amphoteric derivatives of gum include the following: (1) simultaneously modifying gum with anionic and cationic modifier [83] and (2) modifying gum with an amphoteric modifier [84].

\section{Hydrophobic derivatives}

The natural gums are mainly hydrophilic and soluble in aqueous medium, but it cannot meet the requirements for the application in organic solvent system. Other polysaccharide (i.e., starch, cellulose, chitosan) may form hydrophobic derivatives by introducing short chain hydrocarbon substituents through etherification reaction and show solubility in organic solvents [85].

\section{Techniques of Derivatisation}

"Physiosorption", "grafting," and "crosslinking" are the techniques used for the process of derivatisation of a polymer. The term physiosorption is related to physical attractive forces which is a reversible and is achieved by the end functionalized polymers on to the solid surface or self - assembly of polymeric surfactants. The term "grafting" can be described as the covalent attachment process and irreversible. Grafting can be done either by "grafting to" in which functionalized monomer react with backbone polymer to form grafted one or "grafting from " in which substrate is treated with some method to generate immobilized initiators followed by polymerization. The "crosslinking" is irreversible process in which the association of polymers through a chemical bond occurs. It may be intra and intermolecular.

\section{Grafting by chemical routes}

In this method redox reagents are used which produce the free radicals. These free radicals are then used for grafting. The technique is simple to carry out, feasibility exists at room temperature and also the extent of grafting can be controlled by controlling the reaction variables like reaction time, temperature, monomer concentration.

The probable reaction pathways are described below.

\section{With Fenton's reagent $\left(\mathrm{Fe}^{2+} / \mathrm{H}_{2} \mathrm{O}_{2}\right)$}

An hydroxyl radical is generated by the reaction of $\mathrm{Fe}^{2+}$ and $\mathrm{H}$. The hydroxyl radical abstracts the hydrogen atom from the polymeric substrate, producing the free radical on it. The monomer molecules in the vicinity of the polymeric substrate become the acceptor of the radicals, which results in chain initiation. Thereafter, they become the free - radical donors to the neighboring molecules. In this way, the grafted chains usually grow. These grafted chains terminate by coupling to yield the grafted copolymer [86]

(a) With $\mathrm{Fe}^{2+}$ / Persulphate: Persulphate and a ferrous ion act as a source of $\mathrm{SO}_{4}$.

(b) With Persulphate and Reducing Agent: Persulphate and a reducing agent like, sodium bisulphite, thiosulphate, $\mathrm{or}^{\mathrm{Ag}^{+}}$are also the source of $\mathrm{SO}_{4}^{-}$, which subsequently produces $\mathrm{OH}$.

(c) With $\mathrm{Fe}^{2+} /$ Hydroperoxides: Hydroperoxides and $\mathrm{Fe}^{2+}$ generate free radicals via thermal decomposition. The resulting $\mathrm{t}-\mathrm{BuO} \cdot$ participates in hydrogen abstraction to generate $\mathrm{OH}$ and the macro radical on the polymeric backbone.

(d) By Direct Oxidation: In this method, unlike the above ones the radicals are generated on the backbone itself by use of transition metal ions (e.g., $\mathrm{Ce}^{4+}, \mathrm{Cr}^{6+}, \mathrm{V}^{5+}$ and $\mathrm{Co}^{3+}$ ). The metal ions with low oxidation potential are the proper choices for the reaction. These highly reactive ions are responsible for initiating graft copolymerization.

(e) Using Metal Chelates: Controlling redox potential helps in avoiding unwanted reaction. This can be achieved by the use of metal chelates in the grafting reaction. The metal ion forming complex with the monomer decomposes to the free radical, which undergoes a chain transfer to the polymer.

(f) By Indirect Method: The secondary free radicals are generated in the system and may ultimately induce the free - radical sites required for grafting [87].

\section{Crosslinking}

It also refers to use of different crosslinking agents and initiators; the mechanism is similar to the grafting reaction. In this chemical pretreatment (e.g., ozonation, diazotization, and xanthation) is done on the polymer backbone which generates free radicals that provide sites for grafting. It occurs till all monomers have been consumed. In these reactions $\mathrm{Ri}<<\mathrm{Rp}$, where, as for the conventional free - radical grafting, $\mathrm{Ri}>\mathrm{Rp}$ ( $\mathrm{Ri}$ and $\mathrm{Rp}$ are the rate of initiation and propagation). Also dynamic equilibrium occurs between a propagating radical and dormant species. Predetermination of molar mass of the grafted/ crosslinked polymer molecules is possible by use of osmometry and 


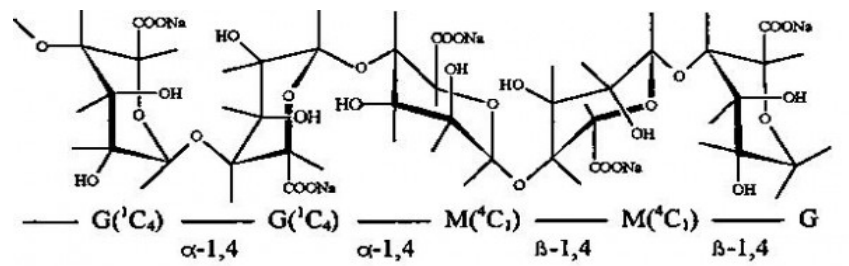

Figure 2: Chemical structure of alginate.

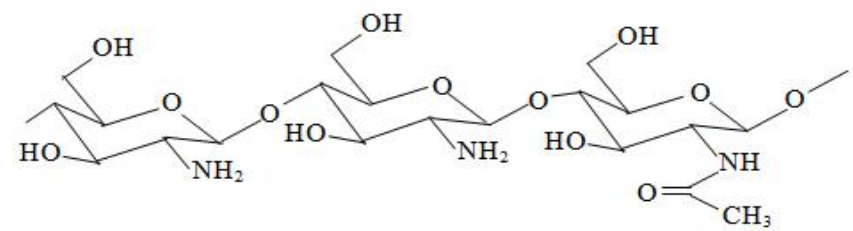

Figure 3: Chemical structure of chitosan.

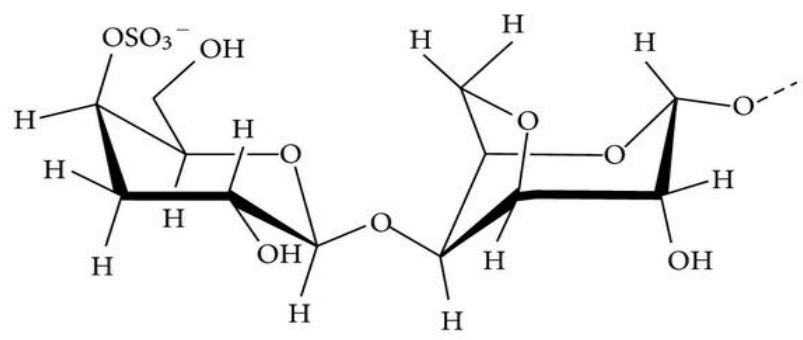

Figure 4: Chemical structure of kappa carrageenan.

small-angle laser light scattering [88]. Crosslinked sodium alginate and hydroxyl ethyl cellulose beads were used for controlled release of ibuprofen and diclofenac sodium [89].

\section{Enzymatic technique}

The graft and crosslinking reactions with the help of enzymes (i.e., biological proteincious catalyst) are the features of this technique. Oxido reductase enzymes (horse- radish peroxidase, Tyrosinase, etc.) are focused in the literature as they are capable of forming free radicals (e.g., phenol/amine derivatives) by abstracting electrons or by supplying molecular oxygen to the molecules. The active species formed then either condenses each other or react with the nucleophiles the reactions are milder and there is less use of harsh chemicals. Initiation needs the enzyme to form the free radicals and is followed by non-enzymatic reactions. Enzyme selectivity and specificity makes the reaction simple and offers the potential for better controlling macromolecular structure without the need of protection or deprotection steps. It can be coupled with the other polymerization methods [90].

\section{Applications of Derivatisation}

\section{Alginate}

It is a water-soluble linear polysaccharide extracted from brown seaweed and is composed of alternating blocks of 1-4 linked L-glucoronic and D-mannuronic acid residues as shown in Figure 2. Some modifications of alginate for drug delivery are Alginate combined with chitosan [90], thiolated alginate-albumin nanoparticles [91], alginatepoloxamer microparticles, Hydrated thiolated alginate, alginate-poly (lactic-co-glycolic acid) nano/micro hydrogel matrices, chitosanCa-alginate microspheres, alginate modified by microenvironmental interaction with calcium ion, polyethylene glycol-anthracene modified alginate [92], photocrosslinked heparin-alginate hydrogels, alginateguar gum hydrogel, Micelles/sodium- alginate composite gel beads [93], scleroglucan/alginate/borax gels [94], dual cross linked alginate [95].

\section{Chitosan}

The chemical structure of chitosan has been shown in Figure 3. Some modification of chitosan are carboxymethylation $[96,97]$, carboxyethylation [98], reductive amination with phosphorylcholine glyceraldehydes [99], sulfation [100], $\mathrm{N}$ - or O-acylation alkylation [101-104], quaternarization [105-107], thiolated chitosan [108], phosphorylated chitosan [109,110], grafted chitosan [111]. Chitosan phthalate is less hydrophilic than chitosan succinate. The relative pharmacological efficacy for chitosan phthalate and chitosan succinate microspheres was almost three-fold higher than the efficacy of the oral insulin administration [112]. Among viral and non-viral delivery vectors, the use of non-viral vectors such as chitosan or its derivatives is attractive, since these polymers are biodegradable, biocompatible, with low toxicity and high cationic potential. Even though much of the technology-base has been well established for targeted delivery of plasmid DNA using chitosan and its derivatives, only recently, has the technology been applied to the targeted delivery of si RNA [113]. Derivatives of chitosan have been used in development of micro and nanoparticles [114].

\section{Carrageenans}

Figure 4 gives an idea about the structure of kappa carrageenan. Some modified forms of carrageenan for drug delivery is iotacarrageenan combined with locust bean gum [115], carrageenan combined with gellan gum [116], chitosan/carrageenan nanoparticles [117], agarose-carrageenan hydrogels [118]. Microencapsules with carrageenan-locust bean gum mixture in a multiphase emulsification technique for sustained drug release of gentamycin sulphate.

\section{Guar gum}

Guar gum is a galactomannan as shown in Figure 5. Several modifications of guar gum for drug delivery are graft copolymers of $\mathrm{N}$-Vinyl-2-Pyrrolidone onto guar gum for sorption of $\mathrm{Fe}$ and $\mathrm{Cl}$ ions [119]. Graft copolymer of partially carboxymethylated guar gum-gN-vinyl-2-pyrrolidone [120], Cross-linking of alginate guar gum with glutaraldehyde [121], carboxymethyl guar films for the formulation of transdermal therapeutic systems [122], graft copolymer H-partially carboxy methylated guar gum-g-methacrylic acid [123]. Complexation of cupric ion-guargum-graft-acrylamide [124], yttrium crosslinked guar gum-g-acrylamide gel systems [125], Phosphated cross linked guar gum [126], polyester-guar gum/hydroxyl propyl guar gum [127]. Microspheres of Carboxymethyl Guar Gum used were for In Vitro Release of Abacavir Sulfate [128].

\section{Pectin}

The chemical structure of pectin has been mentioned in Figure 6. To achieve better drug delivery, certain modifications of pectin are done. These are Polyelectrolyte Complex (PEC) film between pectin as an anionic polyelectrolyte and chitosan as a cationic species [129] self-assembling pectin-liposome nano complexes [130], novel pectin-4-aminothiophenole conjugate microparticles [131], pectin/ 
Citation: Pawar HA, Kamat SR, Choudhary PD (2015) An Overview of Natural Polysaccharides as Biological Macromolecules: Their Chemical Modifications and Pharmaceutical Applications. Biol Med (Aligarh) 6: 224. doi: 10.4172/0974-8369.1000224

Page 6 of 9

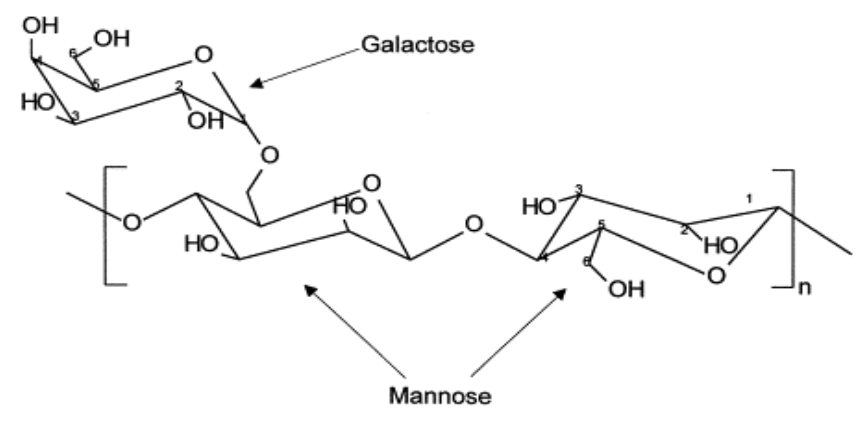

Figure 5: Chemical structure of guar gum.

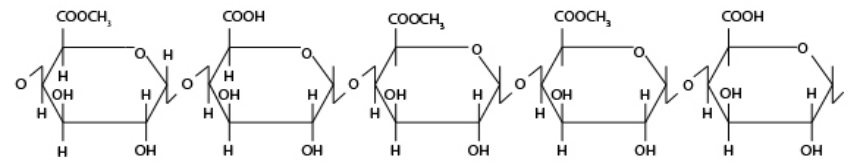

Figure 6: Chemical structure of pectin

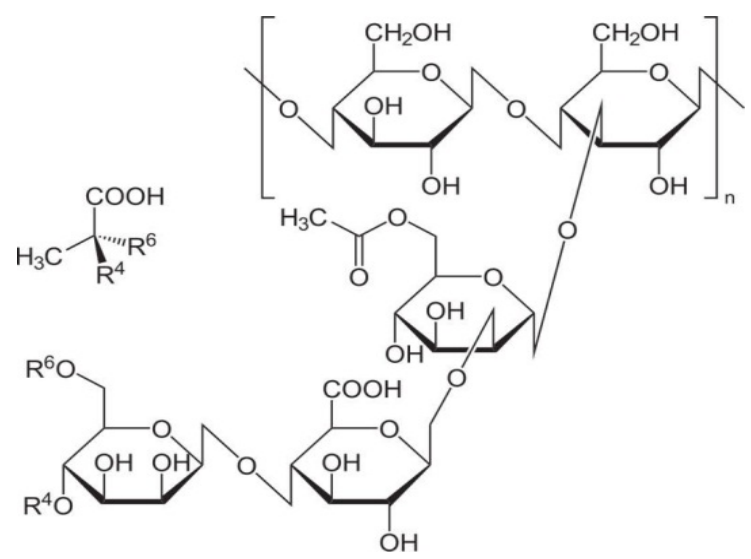

Figure 7: Chemical structure of xanthan gum.

HPMC polymer mixture [132]. Pectin-NH was prepared by modifying the galacturonic acids carboxyl groups with primary amine groups [133], amidated pectin derivatives with n-propyl-,3-aminopropyl-,3propanol or 7-aminoheptyl-substituents [134], thiolated pectin [135], pectin/poly (lactide-co-glycolide) composite matrices [136], mixed pectin/ethylcellulose films, calcium cross-linked pectinate $[137,138]$.

\section{Xanthan gum}

Figure 7 gives the chemical structure of xanthan gum. Some modifications of xanthan for drug delivery are gelatinized starchxanthan gum hydrogel system, acrylamide-grafted- xanthan gum, Graft copolymerization of ethylacrylate onto xanthan gum, xanthan combined with Konjac glucomannan, xanthan combined with boswellia gum (3:1), xanthan gum combined with guar gum(10:20), xanthan gum combined with locust bean gum in 1:1 ratio [139]. Acrylamidegrafted-Xanthan Gum Copolymer Matrix Tablets were used for Oral Controlled Delivery of Antihypertensive Drugs [140].

\section{Conclusion}

Semi-synthetic polymers have wide application in pharmaceutical field. There are numerous natural polymers available. Each of these polymers can be derivatised by different method. They show improved physicochemical properties along with the modification obtained by attachment of particular moiety. These derivatives of polymers can be used for development of many pharmaceutical drug delivery systems. There are several natural polymers which are yet to be derivatized. Thus there is great opportunity to the research /development scientist to develop novel polymers by modification of natural polymers.

\section{Conflict of Interest}

The author(s) declare(s) that there is no conflict of interests regarding the publication of this article.

\section{Acknowledgement}

Authors are very much thankful to Dr. P.S. Gide, Principal of Hyderabad Sindh National Collegiate Boards (HSNCB's) Dr. L. H. Hiranandani College of Pharmacy, Ulhasnagar for his continuous support, guidance and encouragement.

\section{References}

1. William BJ (2008) Ask the Historian: The origin of the polymer concept. J Chem Edu 88: 624-625.

2. Shukla RK, Tiwari A (2012) Carbohydrate polymers: Applications and recent advances in delivering drugs to the colon. Carbohydr Polym 88:399-416.

3. Liu Z, Jiao Y, Wang Y, Zhou C, Zhang Z (2008) Polysaccharides-based nanoparticles as drug delivery systems.Adv Drug Deliv Rev 60:1650-1662.

4. Saravanakumar G, Jo DG, Park JH (2012) Polysaccharide based nanoparticles: A versatile Platform for Drug Delivery and Biomedical Imaging. Curr Med Chem19:3212-3219

5. Satturwar PM, Fulzele SV, Dorle AK (2003) Biodegradation and in vivo biocompatibility of rosin: A natural film-forming polymer. AAPS Pharm Sci Tech 4: $1-6$.

6. Lam KS (2007) New aspects of natural products in drug discovery. Trends Microbial 15: 279-89.

7. McChesney JD, Venkataraman SK, Henri JT (2007) Plant natural products: Back to the future or into extinction? Phytochemistry 68: 2015-2022.

8. Pandey R, Khuller GK (2004) Polymer based drug delivery systems for mycobacterial infections. Current Drug Delivery 1: 195- 201.

9. Chamarthy SP, Pinal R (2008) Plasticizer concentration and the performance of a diffusion-controlled polymeric drug delivery system. Colloids And Surfaces A: Physicochemical and Engineering Aspects 331: 25-30.

10. Alonso-Sande M, Teijeiro D, Remuñán- López C, Alonso MJ (2009) Glucomannan a promising polysaccharide for biopharmaceutical purposes. Eu J Pharm Biopharm 72: 453-62.

11. Guo J, Skinner GW, Harcum WW, Barnum PE (1998) Pharmaceutical applications of naturally occurring water-soluble polymers. PharmSc TechnolToday 1: 254-261.

12. Hirose K, Endo K, Hasegawa K (2004) A convenient synthesis of lepidimoide from okra mucilage and its growth-promoting activity in hypocotyls. Carbohydrate polymers 339; 9-19.

13. Ravi Kumar, Patil MB, Sachin Patil R, Mahesh S (2009) Evaluation of AbelmoschusEsculentus Mucilage as Suspending Agent in Paracetamol Suspension. Intern J PharmTech Res1: 658- 665.

14. Ravi Kumar, Patil MB, Sachin Patil R, Mahesh S (2009) Evaluation of disintegrating properties of Abelmoschusesculentus mucilage. Inter $\mathrm{J}$ Pharm Tech Res 1: 241-246.

15. Ngwuluka NC, Idiakhoa BA, Nep El, Ogajilan, Okafor IS (2010) Formulation and evaluation of paracetamol tablets manufactured using the dried fruit of Phoenix dactylifera Linn as an excipient. Res Pharm Biotech 2: 25-32.

16. Subas Chandra Dinda and BiswajitMukharjee (2009) Gum cordia-A new table binder and emulsifier. ActaPharmaceuticaSciencia 51: 189-198.

17. Khunkitti W, Aromdee C, Vorarat S, Chitropas P (2006) The potential of jackfruit starch for use as suspending agent and emulsifying agent. Songklanakarin J SciTech. 
Citation: Pawar HA, Kamat SR, Choudhary PD (2015) An Overview of Natural Polysaccharides as Biological Macromolecules: Their Chemical Modifications and Pharmaceutical Applications. Biol Med (Aligarh) 6: 224. doi: 10.4172/0974-8369.1000224

18. Sabale V, Patel V, Paranjape A (2012) Isolation and characterization of jackfruit mucilage and its comparative evaluation as a mucoadhesive and controlled release component in buccal tablets. Int J Pharm Investig 2: 61-69.

19. Deveswaran R, Sindhu Abraham, Bharath S, Basavaraj BV, Sharon Furtado (2009) Design and Characterization of Diclofenac sodium tablets containing Tamarind seed polysaccharide as Release retardant. Inter J PharmTech Res 1191-195.

20. Mishra MU, Khandare JN (2011) Evaluation of tamarind seed polysaccharide as a biodegradable carrier for colon specific drug delivery. Inter $\mathrm{J}$ Pharm Pharma Sci 3: 139-142.

21. Ali N, Hossein N, Afagh K, Tarifeh S, Hadi V, Ford JL (2008) An in vitro evaluation of fenugreek mucilage as a potential excipient for oral controlled-release matrix tablet. Drug Development and Industrial Pharmacy 34: 323-329.

22. Malik K, Arora G, Singh I (2011) Locust bean gum as superdisintegrantformulation and evaluation of nimesulide oral dispersible tablet. Polimery wMedycynie 41: 17-28.

23. Venkatarajua MP, Gowdaa DV, Rajeshb KS, Shivakumara HG (2007) Xanthan and locust bean gum (from Ceratoniasiliqua)matrix tablets for oral controlled delivery of propranolol hydrochloride. Asian J Pharm Sci 2: 39-248.

24. Jenita JJL,Vijaya K, Suma R, Raj B, Siddiqca A (2010) Formulation and evaluation of compression coated tablets of mesalazine for colon delivery. Inter J PharmTech Res 2: 535-541.

25. Shin HJ, Ki MH, Yoon B, SW (2006) An, Gastricretentive controlled release mono matrix tablet. Chong Kun Dang Pharmaceutical.Tech Rep.

26. Uner M, Altinkurt T (2004) Evaluation of honey locust (Gleditsiatriacanthos Linn.) gum as sustaining material in tablet dosage forms. IIFarmaco 59: 567573

27. Singh S, Bothara DSB, Singh S (2010) Pharmaceutical characterization of Cassia tora of seed mucilage in tablet formulations. Schol Res Lib 2: 54-61.

28. Mann AS, Jain NK, Kharya MD (2007) Evaluation of the suspending properties of Cassia tora mucilage on sulphadimidine suspension. Asian J ExpSci 21 $63-67$

29. Vendruscolo CW, Andreazza IF, Ganter JLMS, Ferrero C, Bresolin TMB (2005) Xanthan and galactomannan (fromM. scabrella)matrix tablets for oral controlled delivery of theophylline. Inter J Pharms 296: 1-11.

30. Singh K, Kumar A, Langyan N and Ahuja M (2009) Evaluation of Mimosa pudica seed mucilage as sustained-release excipient. AAPS PharmSciTech 10: $1121-1127$.

31. Chopra RN, Nayar SL, Chopra IC (1956). Glossary of Indian Medicinal Plants ( $1^{\text {st }}$ edtn)

32. Sheth NS, Shah NV, Shah NC (2010) Extraction ofmucilage from Ocimumamericanumlinn and its role as disintegrant in tablets formulation. $J$ Global Pharma Tech2: 26-31.

33. PranshuTangri, SatheeshMadhav NV, ShaffiKhurana (2011) Formulation of Paracetamol Suspension using A Novel Bio Anti-Settlant agent from Vignamungo. Intern J PharmTech Res 3: 1234-1237.

34. Basavaraj BV, Naramsetty S (2013) VignaMungo Mucilage - A Natural Polymer in the Design of Matrix Based SR Tablet of Aceclofenac.Inter J Pharm Sci Rev Res 21: 125-130.

35. Kale RH, Joshi UM, Ambhore DP, Sitaphale GR (2009) Evaluation ofEvaluation of DelonixregiaRaf. Endospermic mucilage as tablet binder.Inter $\mathrm{J}$ ChemTech Res 1: 11-15.

36. Ashton WA,Jefferies M, Morley RG, Pass G, Phillips GO, Power DMJ (1975) Physical properties and applications of aqueous solutions of Albiziazygia gum. J Sci Food Agri 26: 697-704.

Odeku OA1, Fell JT (2005) In-vitro evaluation of khaya and albizia gums as compression coatings for drug targeting to the colon. J Pharm Pharmacol 57 163-168.

38. Sarojini S, Kunam SD, Manavalan R, Jayanthi B (2010) Effect of natural gum as a binder in the formulation of diclofenac sodium tablets. Inter J Pharm Sc Res 1: 55-60.

39.daSilveiraNogueira Lima R, Rabelo Lima J, Ribeiro De Salis C, de Azevedo Moreira R (2002) Cashew-tree (Anacardiumoccidentale L.) exudate gum: a novel bioligand tool. BiotechnolApplBiochem 35: 45-53.
40. Kumar R, Patil MB, Patil SR, Paschapur MS (2009) Evaluation of Anacardiumoccidentale gum as gelling agent in aceclofenac gel. Inter J PharmTech Res 1: 695-704.

41. Ofori-Kwakye K, Asantewaa Y, Kipo SL (2010) Physicochemical and binding properties of cashew tree gum in metronidazole tablet formulations. Inter Pharm Pharm Sci 2: 105-109.

42. Panda D, Swain S, Gupta R, Si S, Kanungo SK (2006) Preparation and evaluation of gels from gum of Moringa oleifera. Ind J Pharm Sci 68: 777-780.

Panda DS1, Choudhury NS, Yedukondalu M, Si S, Gupta R (2008) Evaluation of Gum of Moringa oleifera as a Binder and Release Retardant in Tablet Formulation. Indian J Pharm Sci 70: 614-618.

44. Patel BV, Patel D (2011) Study of disintegrant property of Moringa Oleifera gum and its comparison with other superdisintegrants. Inter J ChemTech Res 3. 1119-1124.

45. Morkhade DM, Fulzele SV, Satturwar PM, Joshi SB (2006) Gum copal and gum damar: novel matrix forming materials for sustained drug delivery. Ind $\mathrm{J}$ Pharma Sci 68: 53-58.

46. Morkhade DM and Joshi SB (2007) Evaluation of gum damar as a nove microencapsulating material for ibuprofen and diltiazem hydrochloride. Indian J Pharm Sci 69: 263-268.

47. Osete-Cortina L, Domenech-Carbo MT (2005) Analytical characterization of diterpenoid resins present in pictorial varnishes using pyrolysis-gas chromatography-mass spectrometry with on line trimethylsilylation. J Chromatog A 1065: 265-278.

48. Umekar MJ, Yeole PG (2008) Characterization and evaluation of natural copa gum-resin as film forming material.Intern J Green Pharm 2: 37-42.

49. Janaki B, Sashidhar RB (2000) Subchronic (90-day) toxicity study in rats fed gum kondagogu (Cochlospermumgossypium). Food ChemToxicol 38: 523534.

50. Murthy KVR, Subramanyam GSV (2008) Design and Statistical Optimization of Hupu Gum Based Gastric Floating Drug Delivery Systems of DiltiazemHCl. American Ass Pharma Sci, Atlanta, Ga, USA.

51. Krishna RR, Murthy TEGK (2010) Preparation and evaluation of mucoadhesive microcapsules of glipizide formulated with gum kondagogu: In vitro and in vivo. Acta Pharmaceutica Sciencia 52: 335-344.

52. Nayak BS, Nayak UK, Patro KB, Rout PK (2008) Design and evaluation of controlled release bhara gum microcapsules of famotidine for oral use. Research Journal of Pharmacy and Technology 1: 433-436.

Eagles PF, Stephen AM, Churms SC (1993) Molecular structures of gum exudates from Hakea species. Phytochemistry 34: 709-713.

54. Alur HH, Pather SI, Mitra AK, and Johnston TP (1999) Evaluation of the gum from Hakeagibbosa as a sustained-release and mucoadhesive component in buccal tablets.Pharm Develop Technol4: 347-358.

55. Okafor IS, Chukwu A, Duala K (2001) Some physicochemical properties of grewia gum, Nigeria. J Polym Sci Tech 2: 161-167.

56. Martins E, Christiana I, and Olobayo K (2008) Effect of Grewia gum on the mechanical properties of Paracetamol tablet formulations. Afr $\mathrm{J}$ Pharm Pharmacol 2: 1-6.

57. Nep El and Conway BR (2010). Polysaccharide gum matrix tablets for ora controlled delivery of cimetidine. J Pharm Sci Res 2: 708-716.

58. Ogaji I, Okafor IS (2011) Potential of Grewia gum as film coating agent: some physicochemical properties of coated praziquantel tablets. Inter J Pharm Res 3: $16-19$.

59. Muzib YI, Kurri PS (2011) Formulation and evaluation of gum olibanum-based sustained release matrix tablets of ambroxol hydrochloride, Inter $\mathrm{J}$ Pharm Pharmaceu Sci 3: 195-199.

60. Prasanthi NL, Manikiran SS, Rao NR (2011) In vitro drug release studies of ziprasidone from tablets using natural gums from biosphere. Archives App Sci Res 3: 513-519.

61. Chowdary KPR, Mohapatra P, Krishna MNM (2008) Evaluation of olibanum resin as microencapsulating agent for controlled drug delivery. Ras ${ }^{-}$ayan $\mathrm{J}$ Chem 1: 99-104.

62. Bamiro OA, Sinha VR, Kumar R, Odeku OA (2010) Characterization and 
Citation: Pawar HA, Kamat SR, Choudhary PD (2015) An Overview of Natural Polysaccharides as Biological Macromolecules: Their Chemical Modifications and Pharmaceutical Applications. Biol Med (Aligarh) 6: 224. doi: 10.4172/0974-8369.1000224

Page 8 of 9

evaluation of Terminaliarandii gum as a binder in carvedilol tablet formulation. Acta Pharmaceutica Sciencia 52: 254-262.

63. Rao KM, Gnanaprakash K, Badarinath AV (2010) Preparation and evaluation of flurbiprofen gel; mucilage of Cocculushirsutus leaf powder as gel base. Inter J PharmTech Res 2: 1578-1583.

64. Choi S, Chung MH (2003) A review on the relationship between Aloe vera components and their biologic effects, Seminars in Integrative Medicine 1: $53-62$.

65. Ahad AH, Kumar CS, Kumar B (2010) Development and in vitro evaluation of glibenclamide Aloe barbadensis miller leaves mucilage controlled release matrix tablets. Inter J PharmTech Research 2: 1018-1021.

66. Jenita JJL, Vijaya K, Suma R, Raj B (2010) Formulation and evaluation of compression coated tablets of mesalazine for colon delivery. Inter J PharmTech Res 2: 535-541.

67. Janiand GK, Shah DP (2008) Assessing Hibiscus rosa-sinensis Linn as an excipient in sustained-release tablets. Pharm Tech 32: 62-75.

68. Gangurde AB, Malode SS, Bhambar RS (2008) Preliminary evaluation of neem gum as tablet binder. Ind J Pharm Edu Res 42: 344-347.

69. Abdul AH, Suresh KC, Kumar BA (2010) Permeation studies of diclofenac sodium from ficuscarica fruit mucilage matrices for transdermal delivery. Intern J ChemTech Res 2: 937-941.

70. Venkaiah K, Shah JJ (1984) Distribution, development and structure of gum ducts in Lanneacoromandelica (Houtt.) merril. Annals of Botany 54: 175-186.

71. Paul J (1953) Principles of Polymer Chemistry. The George Fisher Baker NonResident Lectureship in Chemistry at Cornell University, Cornell University Press, USA, 39.

72. Dav'e V, McCarthy SP (1997) Review of konjacglucomannan, J Environ Polym Degr 5:237-241.

73. Alvarez-Mance nido F, Landin M, ILacik I, Mart'inez-Pacheco R (2008) Konjacglucomannan and konjacglucomannan/xanthan gum mixtures as excipients for controlled drug delivery systems, Inter J Pharm, 349:11-18.

74. Gurpreet Arora, KaranMalik, Inderbir Singh (2011) Formulation and Evaluation of Mucoadhesive Matrix Tablets of Taro Gum: Optimization Using Response Surface Methodology, Polimery w Medycynie 41:23-34

75. Dodi G, Hritcu D, PopaMI (2011) Carboxymethylation of guar gum: synthesis and charac- terization. Cellulose Chemistry Tech 45: 171-176.

Chourasia MK, Jain SK (2004) Polysaccharides for colon targeted drug delivery. Drug Deliv 11: 129-148

77. Edgar K (2004) Organic cellulose esters. In: Mark HF (ed) Encyclopedia of polymer science and technology, Wiley, New York: NY. 9: 129-158.

78. Chen YL (2008) Preparation and characterization of water soluble chitosan gel for skin hydration. Mph thesis. Univ Sains Malaysia 1-181.

Zhang Q, Li N, Liu X, Zhao Z, Li Z, et al. (2004) The structure of a sulfated galactan from Porphyrahaitanensis and its in vivo antioxidant activity. Carbohydr Res 339: 105-111.

80. Dutta PK, Dutta J, Tripathi VS (2004) Chitin and Chitosan: Chemistry, properties and application . J sci ind res 63: 20-31.

81. Martindale's (2009) The complete Drug Reference, Pharmaceutical press I:

82. Gautier SJ, Lecourtier (1991) Polym. Bull. (Berlin) 26: 41.

83. Hatada, Kitayama (2006) NMR Spectroscopy of Polymers, ISBN: 3-540-402209, Springer Laboratory Manuals in Polymer Science,

84. Prabhanjan H, Gharia MM, Srivastava HC (1989) Guar gum derivatives. Part I: preparation and properties. Carbohy Polym 11: 279-292.

85. Lapasin R, Pricl S, Tracanelli P (1991) Rheology of hydroxyethyl guar gum derivatives. Carbohydrate Polym 14: 411-427.

86. Fenton HJH (1894) Oxidation of tartaric acid in presence of iron. J Chem Soc Trans 65: 899-911.

87. Pepenzhik MA, Virnik AD, Rogovin ZA (1969) Synthesis of graft cellulose copolymers and calcium salt of poly (acrylic acid), VysokomolSoedinSer B 11: 245-250.
88. Stepto RFT, Gilbert RG, Hess M, Jenkins AD, Jones RG, et al. (2009) Dispersity in Polymer Science. Pure App Chem81: 351-353.

89. Krishna Rao KSV, Subha MCS, Vijaya Kumar Naidu B, Sairam MN Mallikarjuna N, et al. (2006) Controlled Release of Ibuprofen and Diclofenac Sodium through the Beads of Sodium Alginate and Hydroxy Ethyl Cellulose Blends. J. Appl. Polym. Sci, 102: 5708-5718.

90. Amit B, James W. Rawlins Paramita Ray (2008) Polymer grafting and crosslinking, Published by John Wiley \& Sons, Inc., Hoboken, New Jersey page numbers: $20-23$.

George M1, Abraham TE (2006) Polyionic hydrocolloids for the intestinal delivery of protein drugs: alginate and chitosan--a review. J Control Release 114: 1-14

92. Martinez, Iglesias I , Lozanob R , Teijon J , Blanco M (2011) Synthesis and characterization of thiolated alginate-albumin nanoparticles stabilized by disulfide bonds. Evaluation as drug delivery systems Carbohydr Polym 83: 1311-21.

Wells LA, Sheardown H (2011) Photosensitive controlled release with polyethylene glycol-anthracene modified alginate. Eur J Pharm Biopharm 79: 304-313.

94. Huang X, Xiao Y, Lang M (2011) Micelles/sodium-alginate composite gel beads: a new matrix for oral drug delivery of indomethacin. Carbohydr Polym. 87: 790-798.

Matricardi P, Onorati I, Coviello T, Alhaique F (2006) Drug delivery matrices based on scleroglucan/alginate/borax gels. Int J Pharm 316: 21-28.

96. Gong R, Li C, Zhu S, ZhangY, DuY, et al. (2011) A novel pH-sensitive hydrogel based on dual cross linked alginate/N- -glutaric acid chitosan for oral delivery. J Cont Rel 85: 869-874.

97. Lu G, Kong L, Sheng B, Wang G, Gong Y, et al. (2007) Degradation of covalently cross-linked carboxymethyl chitosan and its potential application for peripheral nerve regeneration. Eur Polym J 43: 3807-3818

98. Jiang H, Wang Y, Huang Q, Li Y, Xu C, et al. (2005) Biodegradable hyaluronic acid/N-carboxyethyl chitosan/protein ternary complexes as implantable carriers for controlled protein release. Macromol Biosci 5: 1226-1233.

99. Tiera MJ, Qiu XP, Bechaouch S, Shi Q, Fernandes JC, et al. (2006) Synthesis and characterization of phosphorylcholine-substituted chitosans soluble in physiological pH conditions. Biomacromolecules 7: 3151-3156.

100. Zhang C, Qu G, Sun Y, Wu X, Yao Z, et al. (2008) Pharmacokinetics, biodistribution, efficacy and safety of $\mathrm{N}$-octyl-O-sulfate chitosan micelles loaded with paclitaxel. Biomaterials 29: 1233-1241.

101. Félix L, Hernández J, Argüelles-Monal WM, Goycoolea FM (2005) Kinetics of gelation and thermal sensitivity of $\mathrm{N}$-isobutyryl chitosan hydrogels. Biomacromolecules 6: 2408-2415.

102. Badawy ME, Rabea El, Rogge TM, Stevens CV, Smagghe G, et al. (2004) Synthesis and fungicidal activity of new N,O-acyl chitosan derivatives. Biomacromolecules 5: 589-595.

103. Zhu A, Shan B, YuanY, Shen J (2003) Preparation and blood compatibility of phosphorylcholine- bonded O-butyrylchitosan. Polymer International 52: 81 85 .

104. Kubota N, Tatsumoto N, Sano T, Toya K (2000) A simple preparation of half $\mathrm{N}$-acetylated chitosan highly soluble in water and aqueous organic solvents. Carbohydr Res 324: 268-274.

105. Kang HM, Cai YL, Deng JJ, Zhang HJ, Liu YF, Tang PS (2006) Synthesis and aqueous solution behavior of phosphonate functionalized chitosans. Eur Poly J 42: $2678-2685$

106. Huang RH, Chen GH, Sun MK, Hu YM, Gao CJ (2007) Preparation and characterization of quaternized chitosan/poly (acrylonitrile) composite nanofiltration membrane from epichlorohydrin cross-linking. Carbohydr Polym70: 318-323.

107. Murata JI, Ouchi YC, Ohya T (1996) Possibility of application of quaternary chitosan having pendant galactose residues as gene deliverytool. Carbohydr Polym 29: $69-74$

108. Sashiwa, H, Kawasaki N, Nakayama A (2003) Chemical modification of chitosan. Part 15: Synthesis of novel chitosan derivatives by substitution of hydrophilic amine usingN-carboxyethyl chitosan ethyl ester as an intermediate. Carbohydr Res 338: 557-561.

109. Bernkop-Schnürch A, Hornof M, Zoidl T (2003) Thiolated polymers--thiomers: 
Citation: Pawar HA, Kamat SR, Choudhary PD (2015) An Overview of Natural Polysaccharides as Biological Macromolecules: Their Chemical Modifications and Pharmaceutical Applications. Biol Med (Aligarh) 6: 224. doi: 10.4172/0974-8369.1000224

synthesis and in vitro evaluation of chitosan-2-iminothiolane conjugates. Int $\mathrm{J}$ Pharm 260: 229-237.

110. Sakairi N, ShiraiA, MiyazakiSH (1998) Surface and Interface-New Functions of Biorelated Polymers I. Synthesis and Properties of Chitin Phosphate. Kobunshi Ronbunshu (Jap J Polym Sci Technol) 55: 212-213.

111. Gulay B, Meltem Y, Yakup AM (2003) Affinity dye-ligand poly(hydroxyethyl methacrylate)/chitosan composite membrane for adsorption lysozyme and kinetic properties. Biochem Eng J 13:35-42

112. Rudzinski WE, Aminabhavi TM (2010) Chitosan as a carrier for targeted delivery of small interfering RNA. Int J Pharm 399: 1-11.

113. Agnihotri SA, Mallikarjuna NN, Aminabhavi TM (2004) Recent advances on chitosan-based micro- and nanoparticles in drug delivery. J Control Release 100: $5-28$

114. Ubaidulla U, Khar RK, Ahmad FJ, Tripathi P (2009) Optimization of chitosan succinate and chitosan phthalate microspheres for oral delivery of insulin using response surface methodology. Pharm Develop Technol 14: 96-105.

115. Suzuki S, Lim JK (1994) Microencapsulation with carrageenan-locust bean gum mixture in a multiphase emulsification technique for sustained drug release. J Microencapsul 11: 197-203.

116. Rodriguez-Hernandez Al (1999) Dynamic visco elasticity behaviour of IgellanCarrageenan and gellan-Xanthan gels. Food hydrocolloids. 13: 59-64.

117. Tapia C, Corbalan V, Costa E, Gai M, Yazdani-Pedram M (2005) Study of the release mechanism of diltiazem hydrochloride from matrices based on chitosan-alginate and chitosan-carrageenan mixtures. Biomacromolecules 6: 2389-2395.

118. Sjoberg H, Persson S, Caram-Lelham N (1999) How interactions between drugs and agarose-carrageenan hydrogels influence the simultaneous transport of drugs. J Cont Rel 59:391-400.

119. Sharma RL (2011) Synthesis and characterization of graft copolymers of $\mathrm{N}$-Vinyl-2-Pyrrolidone onto guar gum for sorption of $\mathrm{Fe}^{2+}$ and $\mathrm{Cr}^{6+}$ ions. Carbohydr Polym 83: 1929-1936.

120. Mishra MM, Yadav M, Mishra D, Behari K (2011) Synthesis of graft copolymer(CmgOH-g-NVP) and study of physicochemical properties: Characterization and application. Carbohydr Polym 83: 1749- 1756.

121. Rana V, Rai P, Tiwary A, Singh R, Kennedy J, et al. (2011) Modified gums: Approaches and applications in drug delivery. Carbohydr Polym 83: 10311047.

122. Narasimha Murthy S, Hiremath SR, Paranjothy KL (2004) Evaluation of carboxymethyl guar films for the formulation of transdermal therapeutic systems. Int J Pharm 272: 11-18.

123. Yadav M, Dinesh, Mishra D, Behari K (2011) Synthesis of partially hydrolyzed graft copolymer (H-partially carboxymethylated guar gum- g-methacrylic acid): A superabsorbing material. Carbohydr Polym 85: 29-36.

124. Chattopadhyay A, Bhattacharya D, Singh R (1993) Reversible gel formation induced by ion complexation involving a cupricion-guar gum- graft-acryl amide interaction. Carbohydr Polym 17: 179-186.
125. Chattopadhyay A, Bhattacharya D, Singh R (1995) Studies on the physicochemical nature of yttrium and cupric ion cross linked guar gumg-acrylamide gel systems. Carbohydr Polym 25: 277-283.

126. Gliko-Kabir I, Yagen B, Baluom M, Rubinstein A(2000) Phosphated crosslinked guar for colon-specific drug delivery. II. In vitro and in vivo evaluation in the rat. J Control Release 63: 129-134.

127. Anita G, Sullad, Lata S, Manjeshwar, Tejraj M, et al. (2011) Microspheres of Carboxymethyl Guar Gum for In Vitro Release of Abacavir Sulfate: Preparation and Characterization. J App Polym Sci 122: 452-460.

128. Shenoy M, D'Melo D (2007) Evaluation of mechanical properties of unsaturated polyester-guar gum/hydroxypropyl guar gum composites. J Pharm Pharmaceu Sci 1: 622-628.

129. Ghaffari A, Navaee K Oskoui M, Bayati K, Rafiee-Tehrani M (2007) Preparation and characterization of free mixed-film of pectin/chitosan/Eudragit RS intended for sigmoidal drug delivery. Eur J Pharm Biopharm 67: 175-186.

130. Thirawong $\mathrm{N}$, Thongborisute J, Takeuchi H, Sriamornsak $\mathrm{P}$ (2008) Improved intestinal absorption of calcitonin by mucoadhesive delivery of novel pectinliposome nanocomplexes. J Control Release 125: 236-245.

131. Perera G, Barthelmes J, Bernkop-Schnürch A (2010) Novel pectin-4 aminothiophenole conjugate microparticles for colon-specific drug delivery. J Control Release 145: 240-246.

132. Ugurlu T, Turkoglu M, Gurer US, Akarsu BG (2007) Colonic delivery of compression coated nisin tablets using pectin/HPMC polymer mixture. Eur $\mathrm{J}$ Pharm Biopharm 67: 202-210.

133. Katav T, Liu L, Traitel T, Goldbart R, Wolfson M, et al. (2008) Modified pectinbased carrier for gene delivery: cellular barriers in gene delivery course. J Control Release 130: 183-191.

134. Šimkovicl, kováJ (2009) Amidated pectin derivatives with $\mathrm{n}$ propyl3-aminopropyl-, 3-propanol- or 7- aminoheptyl-substituents. Carbohydr Polym 76: 602-606.

135. Sharma R, Ahuja M (2011) Thiolated pectin: Synthesis, characterization and evaluation as a mucoadhesive polymer. Carbohydr Polym 85:658-663.

136. Liu L, Won YJ, Cooke PH, Coffin DR, Fishman ML, et al. (2004) Pectin poly(lactide-co-glycolide) composite matrices for biomedical applications. Biomaterials 25: 3201-3210.

137. Bose A, Elyagoby A, Wong TW (2014) Oral 5-fluorouracil colon-specific delivery through in vivo pellet coating for colon cancer and aberrant crypt foci treatment. Int J Pharm 468: 178-186.

138. Hiorth M, Versland T, Heikkilä J, Tho I, Sande SA (2006) Immersion coating of pellets with calcium pectinate and chitosan. Int J Pharm 308: 25-32.

139. Sreenivasa Rao B, Prasanna RY, Mary S (2000) Design and studies of gum karaya matrix tablet. Inter J Pharm Exp 239-242.

140. Raghavendra C, Mundargi , Sangamesh AP, Tejraj M, Aminabhavi (2007) Evaluation of Acrylamide-grafted-Xanthan Gum Copolymer Matrix Tablets for Oral Controlled Delivery of Antihypertensive Drugs, Carbohydr Polym 69: 130-141 